\title{
Issues in Dry Port Location and Implementation in Metropolitan Areas: The Case of Sydney, Australia
}

\author{
John Black ${ }^{a}$, Violeta Roso ${ }^{b}$, Eli Marušićc , Nikolina Brnjac ${ }^{d}$
}

The basic idea behind the concept of a dry port is a more efficient seaport access, movement of the seaport's interface inland with the shift of flows from road to rail. The application of the concept results in a reduction of road transport to/from the seaport together with the associated broad social and environmental benefits. This paper examines the complex factors influencing the timeframes and location of close inland intermodal terminals with dry port characteristics - metropolitan intermodal terminals, as they are usually referred to - and their implementation, with a case study of the Sydney metropolitan region and Port Botany, Australia. The issues surrounding suburban freight terminals are a sub-set of the wider social and environmental problems of the interactions of seaports with

\section{KEY WORDS}

$\sim$ Dry port

$\sim$ Inland intermodal terminals

$\sim$ Metropolitan area

$\sim$ Location

$\sim$ Sydney

a. School of Civil and Environmental Engineering, UNSW, Australia

e-mail: j.black@unsw.edu.au

b. Chalmers University of Technology, Technology management and economics, Gothenburg, Sweden

e-mail: violeta.roso@chalmers.se

c. University of Split, Faculty of Maritime Studies, Split, Croatia

e-mail: emarusic@pfst.hr

d. University of Zagreb, Faculty of transport and traffic sciences, Zagreb, Croatia

e-mail:nbrnjac@fpz.hr

This paper is an extended version of IMSC 2017 conference work.

doi: 10.7225/toms.v07.n01.004

This work is licensed under (cc) BY their hinterland. Port Botany and its close inland intermodal terminals are very distinctive: there are very few ports in the world with such a well-developed network of close inland intermodal terminals. Nevertheless, the Moorebank terminal was first mooted in 2003 but the latest plans anticipate operations commencing in 2018. The paper illustrates some problematic aspects of long timeframes for the development of significant freight infrastructure.

\section{INTRODUCTION}

The increasing container volumes handled in seaports require adequate land to be available nearby for port-associated functions and an efficient inland multi-modal transport access. Some ports are physically constrained so that the ports and /or port terminal operators have become involved in developing dry ports (Roso, 2008; Ng and Gujar, 2009; Wilmsmeier et al., 2011). Whilst dry ports and their functions may be classified by distance from the port: close, midrange and distant (Roso et al., 2009), this paper focuses on the close dry ports - typically those located in large metropolitan areas, also referred to as suburban freight terminals. Services such as transshipment, storage, consolidation, depot, track and trace, maintenance of containers, and customs clearance are available at dry ports. This paper examines the complex factors influencing the location of close inland intermodal terminals with dry port characteristics - metropolitan intermodal terminals as they are usually referred to - and their implementation, with a case study of the Sydney metropolitan region and Port Botany, Australia.

The concept of a dry port should facilitate a more efficient port access, movement of the seaport's interface inland with the shift of flows from road to rail resulting in a reduction of road transport to/from the seaport together with associated broad social and environmental benefits (Henttu and Hilmola, 2011; 
Hanaoka and Regmi, 2011; Roso, 2013). Various types of inland intermodal terminals that fit into the concept of dry ports have been developed and studied around the world, e.g. in China (Beresford et al., 2012), Japan (Yoshizawa, 2012), India (Ng and Gujar, 2009), the United States (Rodrigue et al, 2010; Roso et al., 2015), Asia (Hanaoka and Regmi, 2011), Russia (Korovyakovsky and Panova, 2011), Australia and New Zealand (Roso 2008 and 2013), and Europe (Flämig and Hesse, 2011; Henttu and Hilmola, 2011; Monios, 2011; Bask et al, 2014).

In the case of seaports in the metropolitan Sydney over the past five decades, we can wonder about: why, once the location for a new port was selected by the NSW Government to relieve the fragmented and site-constrained port facilities in Port Jackson, there was insufficient land available for a longer-term expansion of the new port; what inland terminals/dry ports were selected; what have been the issues surrounding the implementation of dry ports in Sydney; whether the implementation of these dry ports had the desired effects of switching containers from road to rail; what the contemporary issues in the implementation of dry ports are, especially in the planning of the Moorebank intermodal terminal that started in 2003 with the operations to commence in 2017.

The methodology adopted in the examination of the issues in the implementation of dry ports is as follows. To set the context for the case study of metropolitan Sydney, we compare the recommendations associated with resolving Port Botany's environmental and social problems against how successive governments have formulated palliative policies based on Butlin (1976), Rimmer and Black (1982), Black and Styhre (2016), other inquiries (for example, NSW Parliamentary Librarian, 1976; NSW Government, 1980 a,b, 2011; Infrastructure Partnership Australia, 2007). This historical research is supported by studies based on in-depth interviews with the key stakeholders on ports and dry ports (Roso, 2008; Roso, 2013; Roso et al. 2015). The interviews in these studies have been undertaken with different actors of the transport system, such as seaport managers, inland terminal managers, rail and road operators, as well as policy makers. In addition, secondary data sources, such as internal company reports and internet-based documents, were combined with the site visits in order to insure validity through triangulation (Golicic and Davis, 2012).

\section{INTERMODAL TERMINALS - CONCEPT OF DRY PORTS}

Intermodal transport refers to the freight supply chain using at least two different modes of transport for the movement of intermodal units (containers, semi-trailers or swap bodies) between origin and destination with one bill of lading, i.e. without handling freight itself during transshipment (Rutten, 1998). Reduced energy consumption, optimization of the usage of the main strengths of each mode, reduction of congestion on road networks, and low environmental impacts (Kreutzerberger et al., 2003) are considered to be the advantages of intermodal (road-rail) transport. Inland intermodal terminals should: contribute to intermodal transport, promote regional economic activity, and improve land use and local goods distribution. These features may also be applied to a dry port - an inland intermodal terminal that has direct rail connection to a seaport, and where customers can leave and/or collect their goods in intermodal loading units as if the transaction was directly with the seaport (Roso et al., 2009). As well as transshipment, which a conventional inland intermodal terminal provides, services such as storage, consolidation, depot, track and trace, maintenance of containers, and customs clearance are available at dry ports.

The quality of access to a dry port, and the quality of the road-rail interface, determines the dry port's performance (Bask et al., 2014). However, the quality of inland access depends on the behavior of a large variety of actors such as government planning agencies, regulatory authorities, terminal operators, freight forwarders, transport operators, and port authorities and this requires coordination between all the actors involved (de Langen and Chouly, 2004; Van Der Horst and De Langen, 2008). A scheduled and reliable high-capacity transport by road and rail to and from the seaport is a prerequisite. Bergqvist et al. (2010) identified the following factors affecting the development process and the time needed to establish intermodal road-rail terminals: profitability, financiers, political entrepreneur, location, large local shippers, and traffic authorities. The authors conclude that profitability combined with an enthusiastic and committed political entrepreneur are the most vital factors for the success and pace of the development process (ibid). Implementation of a close dry port in a seaport's immediate hinterland increases the seaport's terminal capacity and with it comes the potential to increase productivity because bigger container ships will be able to call at the seaport (Roso et al., 2009), provided they are not constrained by their draft.

With a dry port implementation, the seaport's congestion due to numerous trucks at the land interface is avoided because one train can substitute some 35 trucks in Europe (Roso et al., 2009). The benefits from distant dry ports derive from the modal shift from road to rail, resulting in reduced congestion at the seaport gates and their surroundings, as well as reduced external environmental effects along the route (Roso et al., 2009). A reduced number of trucks on the roads generate less congestion, fewer accidents, lower road maintenance costs, and less vehicle emissions. Although road carriers would lose market share in countries such as Australia, where long trailers are restricted to pass through city roads, a dry port is a good solution from their perspective as well. In addition to the general benefits to the environment and the quality of life by shifting flows from road to rail, the dry port concept mainly offers seaports a possibility to increase the throughput without physical expansion at the site 
summarizes the factors that influence dry ports' implementation and operations and, consequently, their success (Table 1); the same has been adapted with new references.

\section{PORT BOTANY - HISTORICAL DEVELOPMENT}

A historical perspective is taken in order to understand the necessity of implementing suburban freight terminals in metropolitan Sydney. The port functions on Port Jackson (Sydney Harbour) had become increasingly constrained in the postSecond-World-War era. The trucks moving containers in and out of Mort Bay had to use the narrow residential streets of Balmain where protests from Residents' Action Groups (one of the first urban environmental lobby groups formed in Sydney) forced the Government into action. The NSW State Government wanted to maintain Sydney as Australia's premier port. A decision was made in 1969 to construct container facilities on Botany Bay. Its construction started in June 1971, the year before environmental impact assessment and the subsequent public inquiry became NSW Government policy. Brotherson (1975) explains the relevant history behind the need to relocate some port functions from Port Jackson to an entirely new port on the reclaimed land in Botany Bay. The new port involved the physical transformation of Botany Bay through dredging, construction of a high breakwater to counter storm surges in the bay, and reclamation of a large area (the plan called for 600 hectares of reclaimed land from the Bay) at a cost of about AUD 604 million in 2014 prices (Brotherson, 1975; Black and Styhre, 2016). A V-shaped entrance channel 19.2 meters deep was dredged in the mouth of Botany Bay to accommodate 200,000 dwt tankers ostensibly designed for petroleum imports and bulk cargoes. In 2016, the maximum draught was 12.7 meters.

From its inception, some major problems have arisen since the port site on Botany Bay was selected - not least the highly constrained site, container truck generation and the imperatives of finding metropolitan locations for intermodal freight terminal. Black and Styrhe (2016) describe the details of "six crises of the state". In this accommodation of change, conflict may intensify, or it may be resolved in one location only to reappear elsewhere, or it may be resolved to the satisfaction of most (if not all) groups (Rimmer and Black, 1982). In the case of Port Botany it was clearly a sub-optimal location - on a small site heavily constrained landward for any future expansion.

The problem of the site chosen for Port Botany, and the need for dry ports, was recognized as soon as the Government's plan was announced. A stellar group of Australian researchers promoted the preparation of reports on the Australian environmental situation, similar to those produced at that time by the US National Academy of Sciences. In 1970, the Council of the Australian Academies of Sciences, i.e. Social Sciences and Humanities, set up a Standing Committee on the Environment, a National Committee on the Environment, and established working groups and ad hoc committees that prepared reports on many environmental problems. A research proposal of looking at problems of the environmental change in some longoccupied urbanized part of Australia won support and it was decided to focus on Botany Bay. Further details on the Botany Bay Project can be found in Black and Styhre (2016). There were several cogent reasons for selecting this case study, including that the NSW Government Maritime Services Board had plans to establish a new port in Botany Bay. Discussions between the Academy of Science and the Minister for Environmental Control of the New South Wales Liberal Government secured the state government support. Discussions between representatives of the three Academies and the ministers of the recently elected Whitlam Federal Labor Government secured a promise of AUD 1,035 million research grant over five years (AUD 10,130 million in current prices).

Eighteen projects, each involving unpaid services and contracts, were approved, of which one study focused on the impact of Port Botany. The Botany Bay Project made specific suggestions about Port Botany around the general procedural issues, proposed construction, coal loader, container terminals, amelioration and compensation, total environment and administrative proposals. The report was successful in advocating the administrative and procedural change: the NSW Environmental Planning and Assessment Act became law in 1979, and Australia's commitment to ecologically sustainable development since the 1990s has ensured that the major projects, such as a new port, are evaluated from the economic, social and environmental perspectives; NSW Department of Treasury now plays a pivotal role in the appraisal of infrastructure proposals irrespective of whether generated by the public or the private sector of the economy; ports are operated in NSW as private entities subject to broader Commonwealth and State regulations. The greatest physical legacy of the Botany Bay Project was the removal of the proposed coal loader to Port Kembla, about 90 $\mathrm{km}$ south of Sydney, and the suspension of the later phases of the NSW Maritime Services Board plans - described as " a remarkable willingness to commit public funds to a grandiose but illconceived port design". However, there has been no appetite for the private sector to run the Botany-Marrickville goods railway line to and from the port although the privatization of parts of the extensive Sydney rail network remain on the political agenda of the incumbent NSW Liberal Party.

The richness of these data would allow a lengthy discussion on the relative power amongst the stakeholder groups and how this has shifted over time, but that is beyond the scope of this paper. A few examples will suffice. It is worth noting that resident's action groups in Balmain were largely responsible for forcing the government to relocate port functions from Sydney Harbor to other locations. Nevertheless, "The powers of the 
Maritime Services Board, as harbor owners, port builders and port operators are, at one and the same time, extraordinarily wide and inappropriately narrow" (Butlin, 1976, p. 93). The powerful road lobby has been instrumental in thwarting successive government policy objectives of getting more freight onto rail. Finally, WestConnex - the largest road building program in Australia's history - is aimed at improving, among other things, access to Port Botany, but its implementation is hotly contested by sections of the community (Bacon and Dalley, 2015). Whilst successful in the advocacy of suburban container depots, the transport of containers by rail has been limited and the improvement of rail port access remains an unresolved problem to this day. What were the results of this advocacy in terms of the implementation of suburban container depots, intermodal terminals and dry ports? To answer that question we must establish some criteria for assessing success.

\subsection{Port Botany's Inland Terminals Pre-2010}

The impacts of Botany Bay report drew attention to the port's poor landward connections to the emerging industrial lands in the outer western suburbs of Sydney, limited rail access to the port, constraints imposed by its location (immediately to the port's north-west of Sydney International Airport that now has two parallel runways thrust into Botany Bay restricting any further expansion of wharf in that direction) and, significantly, community tolerance. All of these issues have haunted governments regarding the expansion of Port Botany up to this day. A number of intermodal terminals that were located within the Sydney metropolitan area nearly a decade ago are listed in Table 2. These are primarily located in close proximity to areas of concentrated industrial distribution. The total planned capacity is limited in some cases by the availability of freight train paths. The total estimated capacity of these terminals is $695,000 \mathrm{TEU}$. These intermodal terminals service the port or function as a transfer point for interstate cargoes. Sydney Ports Corporation (2008) recognized the need to expand the intermodal network within Sydney as a prerequisite for a greater use of rail in alignment with a NSW Government transport policy objective - in fact, the expected capacity for TEU containers has increased by over 5.5 times. The NSW Government Metropolitan Strategy outlined a proposed network of additional intermodal terminals in the central-west, south-west and west of metropolitan Sydney to meet the predicted demand (SPC, 20008).

Table 2.

Metropolitan Sydney intermodal terminals pre-2010.

\begin{tabular}{llll} 
Location & Operators & Siding length (meters) & Estimated capacity (TEU) \\
\hline Camellia & Patrick PortLink & 300 & 80,000 \\
\hline Chullora & Pacific National (inter-state) & 680 & 300,000 \\
\hline Cooks River & Maritime Container Services & 500 & 150,000 \\
\hline Villawood & Mannway & 350 & 20,000 \\
\hline Minto & Macarthur Intermodal Shipping & 390 & 45,000 \\
\hline Yannora & Terminal & 500 & 50,000
\end{tabular}

The NSW Government proposed new facilities at Enfield, Moorebank and Eastern Creek. Sydney Ports developed a proposal for an Intermodal Logistics Centre at Enfield that provides an intermodal facility to cater for the demand generated in central-west Sydney. The private sector proposed an expansion of the Macarthur Intermodal Shipping Terminal at Minto and a joint venture arrangement between Kaplan Investment Funds, QR National, and Stocklands for a new intermodal facility at Moorebank (see Section 5). The inclusion of warehousing and freight support services within each site is a mitigation strategy to reduce the number of large truck movements within the local community surrounding the terminal facilities.

\subsection{Port Botany's Inland Terminals Post-2010}

Port Botany is Australia's second largest container port handling over 2 million TEU, approximately one third of the nation's maritime containers. Container volumes are expected to increase annually over the next decade and are projected to reach 7 million TEU by 2031 (Transport for New South Wales, 2016). The export and import of containers are rather balanced in the amount of TEU, with East Asia being the leading region for full container imports. The descriptive details of each terminal follow, but a broad overview of their TEU capacity is contained in Table 3. 
Table 3.

Sydney suburban intermodal terminals.

\begin{tabular}{llll} 
Location & Operator & Capacity* TEU & Comments \\
\hline Chullora & Pacific National & 600,000 & Announced in 2015 increasing from 300,000 to 600,000. \\
\hline MIST & Qube & 200,000 & Capacity as stated on Qube website. \\
\hline Cooks River & MCS & 500,000 & NSW Ports advice. \\
\hline Yennora & Qube & 200,000 & Qube advice. \\
\hline Villawood (Leightonfield) & Toll/DPW & 180,000 & Toll / DP World announcement. \\
\hline Enfield & NSW Ports & 500,000 & Planning approval for 300,000. \\
\hline Moorebank & Qube & $1,550,000$ & $\begin{array}{l}\text { Planned to commence operations in 2017. IMEX and } \\
\text { interstate. }\end{array}$
\end{tabular}

\subsection{Enfield Intermodal Logistics Centre - Project of 2 Decades}

Sydney Ports has developed an Intermodal Logistics Center at its 60 ha marshalling site at Enfield with the purpose of relieving the congested roads by moving more containers by rail to/from Botany. The existing freight line between Port Botany and Enfield / Chullora is a dedicated freight rail line. In 2010, the terminal finally progressed to the construction stage. The plans for the development of the former marshalling yard at Enfield started with planning approval in 1997 (Roso, 2008; Sydney Ports Corporation, 2008) and a statutory environmental assessment (Sinclair Knight Merz, 2005). Numerous obstacles hindered the realization of the plan although the site is located in an industrial and commercial area adjacent to a dedicated freight railway line. The terminal has a warehouse for the packing and unpacking of containers and short-term storage for unpacked cargo, as well as an empty container storage facility depot for later packing or transfer by rail. The terminal was planned for 500,000 TEU per year, but an independent review concluded and recommended that it was too large for the site and suggested a total of 300,000 TEU per year. In December 2015, the rail-based transport company Aurizon entered into the Heads of Agreement with NSW Ports to take on the role as the Intermodal Terminal Operator for the Enfield ILC. Aurizon have undertaken due diligence and operational planning, with a view to commence intermodal operations by the middle of 2016 .

\section{PORT BOTANY EXPANSION AND MOOREBANK INTERMODAL TERMINAL}

The New South Wales Government has aspirations to make Port Botany the largest container port in Australia. Recently, Port Botany has undergone a major expansion of its container port facilities to cope with the growing volumes of trade. The expansion - one of the largest port projects ever to be undertaken in Australia in the past 30 years - entailed the design, construction, procurement and eventual awarding to Hutchison Port Holdings (HPH) of the 3rd stevedore contract (NSW Ports, 2015). The New South Wales Government would retain regulatory oversight of port matters, and the Australian Competition and Consumer Commission (ACCC) has established a price-monitoring regime to ensure transparency. Pilotage and the role of the Harbor Master, as well as the security and emergency response functions, remain with state-owned Sydney Ports. The successful private sector partner was NSW Ports, who obtained the concession for 99 years. The winning consortium - IFM Investors, AustralianSuper, QSuper and Abu Dhabi Investment Authority, made an upfront payment of AUD 5.07 billion - AUD 4.31 billion for Port Botany and AUD 760 million for Port Kembla (Infrastructure Australia, 2014, p. 22). In addition, the consortium pays an annual AUD 5 million to the State Government under the lease agreement. The proceeds will be allocated to the State Government's investment fund, Restart NSW, to help pay for large infrastructure projects (including the WestConnex roads project).

The Australian and NSW Governments identified the Moorebank precinct as part of this growth strategy as a key strategic location to increase intermodal capacity by adding capacity for an additional 2 million TEUs (NSW Government, 2013, p. 122). The Moorebank terminal was first proposed in 2003 while the South Sydney Freight Line, completed in 2013, was first proposed in 1985. The implication is that land-use planning, which has equally long time horizons, also needs to be clearly assessed and Governments need to be made aware of the long-term consequences for freight of their land-use planning decisions (ATRC, 2015).

Given the Commonwealth of Australia's agenda of improving the nation's economic efficiency of national ports 
potential individual impact on the type of accidents that occur (Moorebank Intermodal Company, 2016, Table 9.39). Further investigations by the NSW Roads and Maritime Services have led to a recommended package of works of about AUD 500 million (ibid).

The Liverpool Community Independent Team argued that there are more appropriate, more efficient and more economical solutions for the location of new intermodal terminals. One solution is to move the problem elsewhere - to Eastern Creek. The second solution is to move the problem out of metropolitan Sydney entirely - south to Port Kembla and this will exploit a rail corridor between Maldon and Dombarton - long on the planning books, but a project seen by governments as uneconomical. The Moorebank Intermodal Terminal is another case of the lack of the local community's tolerance of governments planning large infrastructure projects "in their backyards".

\section{CONCLUSION}

The New South Wales Government policy is to achieve a modal share on rail of $40 \%$ of the total container volumes handled at the seaport through different initiatives by year 2031 (i.e. shift of containers from road to rail) to ease pressure on Sydney's already congested roads. Some of the success factors listed in the Table 1 are also noted in this case of Port Botany development. A well-functioning network of terminals is crucial to achieve this goal and in the case of Port Botany there is a clear cooperation between national and state governments on providing land for the terminals. The main success factors, given the multiplicity of agents involved, is to discuss operational agreements in advance within a market driven development framework that is supported by the Government logistics policies. There must be coordination among various government agencies and the willingness for cooperation between the actors of the transport system. Also, there must be a railway to the seaport to allow containers to be switched from road transport; all together is a sub-set of the wider economic, social and environmental problems of the interactions of seaports with their hinterland.

Port Botany and its close inland intermodal terminals are very distinctive because there are very few ports in the world with such a well-developed network of close inland intermodal terminals. Nevertheless, Moorebank terminal was first conceived as early as in the 2000 , but it is scheduled to be operational in 2018. This shows problematic aspect of long timeframes for development of significant freight infrastructure. Even if $40 \%$ of containers on rail share is reached by 2031 - which is unlikely because a communiqué issued in December 2016 by the Port Botany Rail Optimization Group (PBROG) reveals that a positive shift is taking place and rail mode share is tracking at 18.4 per cent for 2016/17 - up from 16.3 per cent in 2015/16 and 13.5 per cent in 2014/15 (Transport for NSW, 2016) - road transport will still more than double during this period.

This paper has examined the complex factors influencing the location of close inland intermodal terminals with dry port characteristics and their implementation with a case study of the Sydney metropolitan region and Port Botany, Australia. The basic idea behind the concept of a dry port is a more economically efficient port access, movement of the seaport's interface inland with the shift of flows from road to rail resulting in a reduction of road transport to/from the seaport together with the associated broad social and environmental benefits. The success in the development of seaports and of inland terminals depends on the behavior of a large variety of actors, such as government planning agencies, regulatory authorities, terminal operators, freight forwarders, transport operators, and port authorities, and coordination between all actors involved.

An important contribution of this paper has been to describe a case study of the planning and progressive implementation the Moorebank Intermodal Terminal. From this we can distil some generic factors that underpin its potential success. There has been clear cooperation between the national and state governments and the private sector on providing land for the terminal that will cover an area approximately the size of the Sydney CBD. The project is being delivered through a public sector-private sector partnership involving a New South Wales State Government Enterprise and SIMTA.

The Port Botany business development plan has included container terminal expansion and port privatization that have clear long-term targets for the future number of containers to be handled in future years, thus guaranteeing freight business for operators (supported by a New South Wales Government policy to achieve a modal share on rail of 28 per cent). There is government support through the construction of a spur line from the terminal to the South Sydney Freight Line and AUD 500 million road upgrades on the network surrounding the terminal.

On what sounds like an echo from the past, the national government has recently released a Smart Cities Plan and noted "urban development pressures around airports, seaports and intermodal facilities need to be carefully managed to prevent these important economic hubs and corridors from being constrained and to reduce their impacts on surrounding communities" (Commonwealth of Australia, 2016, pp. 16). Nevertheless, given the Federal Government's policy of making gateway ports (seaports and airports) the engines of economic productivity, it seems that port-hinterland research funding is essential to support the aspirations of the Smart Cities Plan.

There is an additional layer of complexity to assessing the success when addressing the general logistics or supply-chain management problem and research needs, i.e. the appropriate role of governments and other stakeholders in the planning of 
seaports and dry ports in any urban system. This is essentially a question of political economy, and our case study of Sydney can only provide some guidance. The means of regulating urban system growth, mechanisms of resolving environmental conflicts and the relative power of political parties and different stakeholders and the community to influence planning and development decisions remain as research topics of relevance today when studying maritime ports.

\section{REFERENCES}

ARTC, 2015, 2015-2024 Sydney Metropolitan Freight Strategy, October 2015 (Sydney: Australian Rail Track Corporation).

Bacon, W. and Dalley, E., (2015), New coalition forms against carcinogenic WestConnex, available at: http://westconnex.info/?p=42295\#sthash.cKtLhIHB.dpuf, [accessed 2 April 2015.].

Bask, A., Roso, V., Hämäläinen, E. and Andersson, D., (2014), Development of seaport - dry port dyads: two cases from Northern Europe, Journal of Transport Geography 39 , pp. 85-95., available at:

https://doi.org/10.1016/j.jtrangeo.2014.06.014

Bergqvist, R., Falkemark, G. and Woxenius, J., (2010), Establishing intermodal terminals, World Review of Intermodal Transportation Research 3(3) pp. 285-302., available at:

https://doi.org/10.1504/WRITR.2010.034667

Beresford, A., Pettit, S., Xu, Q. and Williams, S., (2012), A study of dry port development in China, Maritime Economics and Logistics, 14(1), pp. 73-98., available at: https://doi.org/10.1057/mel.2011.17

Black, J., Kyu, T., Roso, V. and Tara, K., (2013), Critical evaluation of Mandalay dry port, Proceedings 5th International Conference on Logistics and Transport 2013 (ICLT 2013), Sustainable Supply Chain Management in Asia Pacific, Doshisha University, Kyoto, pp. 107-114

Black, J. and Styhre, L., (2016), The Sydney Botany Bay Project legacy: Identification and resolution of port-based conflicts, 7th International Congress of Maritime History, Murdoch University, Perth, June 27 June - July 1.

Brotherson, W. H., (1975), Port operations in Australia, Australian Transport, 17(9), pp. $33-35$.

Butlin, N. G. (ed.), (1976), The Impact of Port Botany, Canberra: Australian National University Press.

Commonwealth of Australia, (2016), Smart Cities Plan, Canberra: Australian Government, Department of Prime Minister and Cabinet.

Cullinane, K. and Wilmsmeier, G., (2011), The contribution of the dry port concept to the extension of port life cycles, Böse, J.W. (Ed.) Handbook of Terminal Planning, Operations Research Computer Science Interfaces Series, Vol. 49, Heidelberg, Springer, Heidelberg, pp. 359-380.

De Langen, P.W. and Chouly, A., (2004), Hinterland access regimes in seaports, European Journal of Transport and Infrastructure Research, 4(4), pp. 361-380.

Flämig, H. and Hesse, M., (2011), Placing dry ports: Port regionalization as a planning challenge - The case of Hamburg, Germany and the Süderelbe, Research in Transportation Economics, 33(1), pp. 35-41.

Fullerton, T., (2015), Qube's Moorebank Intermodal Hub a major infrastructure boost, ABC News, Posted 12 June 2015.
Golicic, S.L. and Davis, D.F., (2012), Implementing mixed methods research in supply chain management, International Journal of Physical Distribution \& Logistics Management, 42 (8/9), pp. 726-741., available at:

https://doi.org/10.1108/09600031211269721

Hanaoka, S. and Regmi, M.B., (2011), Promoting intermodal freight transport through the development of dry ports in Asia: An environmental perspective, IATSS Research, 35, pp. 16-23., available at:

https://doi.org/10.1016/j.iatssr.2011.06.001

Henttu, V. and Hilmola, O.P., (2011), Financial and environmental impacts of hypothetical Finnish dry port structure, Research in Transportation Economics, 33(1), pp. 35-41., available at:

https://doi.org/10.1016/j.retrec.2011.08.004

Infrastructure Australia, (2014), Infrastructure Financing (Canberra: Infrastructure Australia).

Infrastructure Partnership Australia, (2007), Integrated Infrastructure Planning - A New Way Forward, Report to Infrastructure Partnership Australia - A Case Study of Sydney Airport and Port Botany Precinct (http://www.sahainternational.com).

Korovyakovsky, E. and Panova, Y., (2011), Dynamics of Russian dry ports, Research in Transportation Economics, 33(1), pp. 25-34., available at: https://doi.org/10.1016/j.retrec.2011.08.008

KPMG, Deloitte and Parsons Brinkerhoff, (2012), Advisory: Department of Finance and Deregulation - Moorebank Intermodal Terminal Project, Detailed Business Case, 12 February 2012, Sydney: KPMG, Deloitte and Parsons Brinkerhoff.

Kreutzerberger, E.; Macharis, K.; Vereecken, L. and Woxenius, J., (2003), Is intermodal freight transport more environmentally friendly than all-road freight transport? A review, Nectar conference, Umeå, Sweden, June 13-15.

Monios, J., (2011), The role of inland terminal development in the hinterland access strategies of Spanish Ports, Research in Transportation Economics, 33(1), pp. 59-66., available at:

https://doi.org/10.1016/j.retrec.2011.08.007

Moorebank Intermodal Company, (2016), Annual Report 2016, (Sydney: Moorebank Intermodal Company, available at: http://www.micl.com.au/aboutus-annualreports/ [accessed 26 January 2017.].

Ng, A. K. Y. and Gujar, G. C., (2009), Government policies, efficiency and competitiveness: The case of dry ports in India, Transport Policy 16, pp. 232-239 available at:

https://doi.org/10.1016/j.tranpol.2009.08.001

NSW Government, (1980a), Commission of Inquiry into the Kyeemagh-Chullora Road (the Kirby Report) Volume I: Containers, Sydney: NSW Government.

NSW Government, (1980b), Report of the Royal Commission of Enquiry into the New South Wales Road Freight Industry (the McDonald Report), Sydney: NSW Government.

NSW Government, (2011), Port Botany and Sydney Airport Transport Improvement Program Submission to Infrastructure Australia, November, Sydney: NSW Government.

NSW Government, (2013), NSW Freight and Ports Strategy, Sydney, NSW Government.

NSW Parliamentary Librarian, (1976), Report of the Botany Bay Port and Environment Inquiry (the Simblist Report). NSW Parliamentary Papers 1976 (Second Session), No. 103, Sydney: Government Printer.

NSW Ports, (2015), Port Botany Expansion, available at: http://www.nswportsbotany. com.au/projects-and-planning/port-botany-expansion/ 
Parsons Brinkerhoff, (2014), Moorebank Intermodal Terminal Project - Environmental Impact Statement, Sydney: Parsons Brinkerhoff for Sydney Intermodal Terminal Alliance.

Rimmer, P.J. and Black, J. A., (1982), Land use - transport changes and global restructuring in Sydney since the 1970's: The container issue. pp. 223-245 of R.V. Cardew, J.V. Langdale and D. Rich (eds), Why Cities Change: Urban Development and Economic Change in Sydney, Sydney: George Allen and Unwin.

Rodrigue, J.-P., Debrie, J, Fremont, A. and Gouvernal, E., (2010), Functions and actors of inland ports: European and North American dynamics, Journal of Transport Geography, 18(4), pp. 519-529, available at:

https://doi.org/10.1016/j.jtrangeo.2010.03.008

Rodrigue, J.P. and Nottebom, T., (2012), Dry ports in European and North American intermodal rail systems: two of a kind?, Research in Transportation Business \& Management 5, pp. 4-15., available at: https://doi.org/10.1016/j.rtbm.2012.10.003

Roso, V., (2008), Factors influencing implementation of a dry port, International Journal of Physical Distribution and Logistics Management 38(10), pp. 782-798. available at:

https://doi.org/10.1108/09600030810926493

Roso, V., (2013), Sustainable intermodal transport via dry ports - Importance of directional development, World Review of Intermodal Transportation Research, 4 (2/3), pp. 140-156, available at:

https://doi.org/10.1504/WRITR.2013.058976

Roso, V. and Lumsden K., (2010), Review of dry ports, Maritime Economics \& Logistics 12(2), pp. 196-213., available at: https://doi.org/10.1057/mel.2010.5

Roso, V. and Rosa, A., (2012), The dry ports in concept and practice, Song DongWook and Panayides, P. M. (Eds) Maritime Logistics: A Complete Guide to Effective Shipping and Port Management, Kogan, London, pp. 179-194.
Roso, V., Woxenius, J. and Lumsden, K., (2009), The dry port concept: Connecting container seaports with the hinterland, Journal of Transport Geography 17(5), pp. 338-345., available at

https://doi.org/10.1016/j.jtrangeo.2008.10.008

Roso, V., Russell, D., Ruamsook, K. and Stefansson, G., (2015), Inland port services for seaport's competitive advantage, World Review of Intermodal Transportation Research, 5(3), pp. 263-280., available at: https://doi.org/10.1504/WRITR.2015.069242

Rutten, B.C.M., (1998), The design of a terminal network for intermodal transport, Transport Logistics, 1(4), pp. 279-298., available at: https://doi.org/10.1163/156857098300155278

Sinclair Knight Merz, (2005), Intermodal Logistics Centre at Enfield Environmental Assessment, Sinclair Knight Merz for SPC (St Leonards).

Sydney Ports Corporation (SPC), (2008), Port Freight Logistics Plan: A Framework to Improve Road and Rail Performance at Port Botany, Sydney Ports Corporation.

Transport for New South Wales, (2016), NSW ports record positive growth in freight on rail, available at: http://www.freight.transport.nsw.gov.au/news/nsw-portsrecord-positive-growth-freight-rail, [accessed on: 27 January 2017.].

Van Der Horst, M.R. and De Langen, P.W., (2008), Coordination in hinterland transport chains: A major challenge for the seaport community, Maritime Economics and Logistics 10 (1-2), pp. 108-129., available at: https://doi.org/10.1057/palgrave.mel.9100194

Wilmsmeier, G., Monios, J. and Lambert, B., (2011), The directional development of intermodal freight corridors in relation to inland terminals, Journal of Transport Geography 19, pp. 1379-1386., available at: https://doi.org/10.1016/j.jtrangeo.2011.07.010

Yoshizawa, J., (2012), JR Freight Company's quest for intermodal freight transport, ICHCA'S Cargo World 2011/2012 